\title{
The Impact of Competition on Debt Ratio of Manufacturing Enterprises in Vietnam
}

\author{
Nguyen Tan Vinh ${ }^{1}$ \\ ${ }^{1}$ Academy of politics region, Ho Chi Minh, Vietnam \\ Correspondence: Nguyen Tan Vinh, Academy of politics region II, 99 Man Thien st, Hiep Phu, Q9, Ho Chi \\ Minh, Vietnam. E-mail: vinhnt@hcma2.edu.vn
}

Received: May 5, 2019 Accepted: May 25, 2019 Online Published: August 29, 2019

doi:10.5539/jms.v9n2p56 URL: https://doi.org/10.5539/jms.v9n2p56

\begin{abstract}
Asymmetric infomation has caused difficulties for investors in the financial market when the enterprises have high competitiveness in the market but there are acts of using unusual capital structure. Investment decisions on the stock market of investors will be negatively affected by asymmetric information. In particular, the manufacturing enterprises have made an important contribution to Vietnam's economic structure. Therefore, the authors conduct research to assess the impact of product market competition on the capital structure of manufacturing enterprises listed in the Vietnam stock market from 2010 to 2018. By analyzing panel data through the Generalized Method of Moments (GMM), the research results indicate: Competitiveness factors HHI has a negative impact on debt ratio (DR) - the results support the predation theory. When businesses are highly competitive, there will be a tendency to reduce the debt ratio. At the same time, the research results also show the variables ROA and CGIR have negative effects on DR. GRTA and NDTS variables do not affect the DR of manufacturing enterprises. The results of this study will help investors to make their decisions more wisely.
\end{abstract}

Keywords: capital structure, competion market, GMM model, panel data

\section{Introduction}

\subsection{Introduce the Problem}

In the international economical integration period, business entities not only come under pressure from their domestic rivals but also have to directly compete with foreign enterprises. Therefore, they need to carefully plan and calculate their strategies before making decisions. Meanwhile, in the severely competitive economic environment, making new investment can help firms guarantee their stability (Moeinaddin et al., 2013). In order to make it, investment attraction, as well as, capital structure policies are two initially important factors to consider in sreategy formulation.

The General Statistics Office said that GDP grew 7.08\% in 2018, the highest increase in 11 years. Accordingly, in the industry and construction sectors, processing and manufacturing industries continue to be a bright spot contributing to economic growth with a high increase of $12.98 \%$. Although this growth rate was lower than 2017 , it was much higher than the average increase in the years 2012-2016. For the whole year of 2018, the industrial production index increased by $10 \%$ over the previous year. In industries, the processing and manufacturing sectors continue to play a key role, boosting the overall growth of the industry with an increase of $12 \%$ (although lower than the 14\% increase of 2017 but still higher than the increase of the years 2012-2016); electricity production and distribution industry ensures sufficient electricity supply for production and consumption of the population with a $10 \%$ increase; water supply and waste and wastewater treatment industry increased by $6.3 \%$; particularly, the mining industry decreased by $2 \%$ (mainly due to the $11 \%$ decrease in crude oil exploitation) (GSO, 2019)

Investment, or in another word, how to adjust the capital structure policy, depends on various determinants. Competitiveness is one of factors that affects the capital structure policy for corporations. Therefore, it is needed to have an insight into the relationship between firms' competitiveness and the ratio of debt in the context of competitive economics (Guney et al., 2011). The relationship between firms' competitiveness and capital structure is, as well, a meaningful topic which has gained universal interest through decades (Myers, 1997; Kovenock \& Phillips, 1995). 
There are so many reseach studies about the relationship between capital structure and competion. Some studies show that competitive companies often tend to reduce debt ratio to pressure businesses with lower competitiveness and weaker financial resources (Bolton \& Scharfstein, 1990; Brander \& Lewis, 1986). Besides, there are also researches that show that enterprises with good performance do not want a reduction in their value by issuing shares. At the same time, according to trade-off theory, these businesses tend to use higher debt ratios to take advantage of financial leverage (Myers, 1984; Phillips, 1995; Guney et al., 2011; Myers, 1984; Phillips, 1995). In the research environment in Vietnam, studies of the impact of competition on capital structure are limited considering the great contribution of the manufacturing industry to the Vietnamese economy. Therefore, the author conducted research to study the impact of competition on capital structure of manufacturing manufacturing enterprises.

\subsection{Literature Review}

Capital structure is a financial term that describe the origin and method of forming firms' capital to buy assets, material means and maintain business activities. Capital structure takes an important role in utilizing firms' activities because it concerns the decisions of combining different sources of capital (Khan, 2012). These sources include long-term debts, short-term debts (known as debts), preferred stocks and common stocks (also known as capital stock). Setting up an optimal capital structure will lead to effective financial performance, as well as, increase firms' competitiveness (Modigliani \& Miller, 1958).

Competitiveness of enterprises is the ability to maintain and expand the market share of enterprises. National competitiveness is the ability of a country to achieve a high and sustainable per capita income ratio (Ajitabh \& Momaya, 2003; Krugman, 1994; Porter, 1997). Moeinaddin et al. explained that the competitiveness of one industry is measured by concentration or scatter ratio of its market share. The more scattering its market share is, the more competitive the industry is and vice versa. They discussed about HHI index which is usually used to evaluate the competitiveness of firms or industries. According to the, HHI is a strong index to assess the competitive capabilities by sectors and ranges from 0 to 1 . The greater the index is, the more the market share concentrates on some particulars enterprises, which means the less competitive the market becomes (Moeinaddin et al., 2013).

Guney et al. have conducted their research in Chinese market and pointed out that: there was a linear, as well as, nonlinear relationship between factors of competition HHI and capital structure (debt ratio) of firms (Guney et al., 2011). Sumitra and Malabika have studied and found the influence of competition scale in product market which some firms have to face in such a developing country as India on decisions of capital structure of that firms (Sumitra \& Malabika, 2011).

\section{Method}

\subsection{Research Model}

The dependent variable is the capital structure and is defined as the ratio of total debt to total assets. The independent variable is product market competition in my thesis. Product market competition can be measured by the Herfindahl-Hirschman Index (HHI). These variables are theoretically sound and powerful indicators of a firm's marrket power (Boghean \& State, 2015; Fosu, 2013; Lindenberg \& Ross, 1981). In addition, the thesis also adds control variables that affect capital structure.

Model: Impact of HHI on Capital structure

$$
D R_{i t}=\beta_{1}+\beta_{2} H H I_{t i}+\beta_{8} S I Z E_{i t}+\beta_{4} G R T A_{i t}+\beta_{6} C_{6 I I R_{i t}}+\beta_{6} N D T S_{i t}+\beta_{7} R O A_{i t}+\mu_{t}
$$

Capital structure variables are dependent variables in the research model and are calculated based on total liabilities/total assets. At the same time, the independent variable is the competition of the business measured by the criteria of Herfindahl-Hirschman Index (HHI) based on the strength of enterprises in the market (Guney et al., 2011; Lindenberg \& Ross, 1981). HHI is measured through the company's market share in the industry.

The research variables are detailed in Table 1 
Table 1. Definition of variables

\begin{tabular}{|c|c|c|}
\hline Variables & Symbol & Definition \\
\hline Dependent variable: & DR & Debt ratio=total liabilities/total assets \\
\hline \multicolumn{3}{|l|}{ Capital structure } \\
\hline \multicolumn{3}{|l|}{ Independent variables: } \\
\hline HHI & HHI & $\mathrm{HHIi}=\left(x \mathrm{xj} / \sum x \mathrm{xj}\right)^{2} x \mathrm{xj}$ is sales of firm $\mathrm{j}$ \\
\hline \multicolumn{3}{|l|}{ Control variables } \\
\hline Profitability & ROA & Operating profit/total assets \\
\hline Firm size & SIZE & Ln (total assets) \\
\hline Growth rate & GRTS & $\left(\right.$ Total sales $_{t}-$ total sales $\left._{t-1}\right) /$ total sales $t_{t-1}$ \\
\hline Non-debt tax shield & NDTS & Depreciation/total assets \\
\hline Capability of generating internal resources & CGIR & Net cash flow of operations/total assets \\
\hline
\end{tabular}

\subsection{Data}

Secondary data are collected from audited financial statements of enterprises from 2010 to 2018 through FiinPro data system provided by StoxPlus Corporation. Data of listed manufacturing enterprises were used. The variables were collected and calculated before inputting data analysis with STATA software. The results describing the collected data indicate that the average DR of the industry is 0.544 , corresponding to $54 \%$. $\mathrm{Mean}_{\mathrm{HHI}}$ reaches 0.007 ; $\mathrm{Mean}_{\mathrm{ROA}}$ of the whole period reached $0.05(5 \%)$ Mean $_{\text {GRTA }}$ total asset growth of 0.53 $\left(53 \% /\right.$ year); Mean $_{\text {NDTS }}$ is 0.22 ; Mean $_{\text {CRIG }}$ is 0.04 .

Table 2. Descriptive statistics of the variables

\begin{tabular}{llllll}
\hline Variable & Obs & Mean & Std. Dev. & Min & Max \\
\hline DR & 2,296 & 0.544229 & 0.223017 & 0.006119 & 0.964188 \\
HHI & 2,295 & 0.007154 & 0.044351 & 0 & 0.022827 \\
ROA & 2,295 & 0.050471 & 0.086043 & -1.75887 & 0.716832 \\
SIZE & 2,296 & 26.86329 & 1.363292 & 20.72017 & 31.08692 \\
GRTA & 2,033 & 0.534917 & 17.38199 & -0.74519 & 783.2474 \\
NDTS & 2,296 & -0.22926 & 0.244106 & -1.89122 & 0 \\
CGIR & 2,286 & 0.04674 & 0.136965 & -0.90688 & 0.831416 \\
\hline
\end{tabular}

\subsection{Methods of Data Analysis}

With analytical data characteristics for companes listed from 2010 to 2018, the panel data model will be used for analysis. The data, after had been collected, were input to the STATA software for analysis. Basic model, such as Fixed effect and Random effect were put in priority. Hausman test was use to find the right model for the real research data between Fixed effect and Random effect (Hausman, 1978).

In case there were some problems in the models, such as autocorrelation, heteroscedasticity, endogeneity, we would use the Difference GMM (Difference Generalized method of moments) of Arellano-Bond (1991) to fix them. The method of Arellano-Bond was designed to correct the fixed effects implied in the error term of the model due to some unchanged characteristics by time of the studied firms, for example, location and types of business can correlate with explanatory variables in the model.

Sagan test (Hansen test or J-test) and Arellano-Bond test would be use to test the appropriateness of the estimation results of GMM. Sargan test determines the appropriateness of instrumental variables in GMM model. This is a test for over-identification restrictions, of which null hypothesis is that instrumental variables are exogenous. Arellano-Bond test, suggested by Arellano-Bond (1991), is used to test for autocorrelation of variance in GMM model in first differenced-errors. Therefore, the difference series studied implicitly have linear correlation-AR(1), the testing results are ignored. Quadratic correlation-AR(2) is tested on the difference series of error terms to detect autocorrelation of error terms at quadratic. Hypothesis H0 of Arellano-Bond test does not have autocorrelation and is applied for the remainder of differences.

\section{Results}

\subsection{Correlation Matrix}

The variables HHI, SIZE, GRTA and NDTS are positively correlated with debt ratio (positive beta coefficient). In particular, DR has the strongest correlation with SIZE (correlation coefficient $=0.35$ ). The factors ROA and 
CGIR have opposite correlation with DR (negative correlation coefficient). However, to clarify the impact of variables on DR capital structure, the author continues to use regression analysis.

Table 3. Correlation matrix

\begin{tabular}{llllllll}
\hline & DR & HHI & ROA & SIZE & GRTA & NDTS & CGIR \\
\hline DR & 1 & & & & & & \\
HHI & 0.0642 & 1 & & & & & \\
ROA & -0.3551 & 0.0136 & 1 & & & & \\
SIZE & 0.3575 & 0.3487 & -0.0246 & 1 & & & \\
GRTA & 0.0185 & -0.0036 & -0.0101 & 0.0109 & 1 & & \\
NDTS & 0.2296 & 0.0615 & -0.1245 & 0.1414 & 0.0269 & 1 & \\
CGIR & -0.2321 & -0.0152 & 0.2955 & -0.0494 & 0.1121 & -0.2913 & 1 \\
\hline
\end{tabular}

\subsection{Regression}

With Hausman test, it shows that FEM model is more suitable than REM model (p-value of Hausman test is less than 0.05). However, with the autocorrelation and heteroskedasticity tests, the FEM model is not reliable for analysis. Endogeneity may have caused these errors. Therefore, the author uses GMM model to analyze in the final regression model. The results show that the reliable GMM model with AR (2) and Hansen test has p-value greater than 0.05 . The result of the GMM model gives that HHI has the negative impact on debt ratio (negative beta and p-value less than 0.05). The SIZE factor has a positive impact on debt ratio (positive beta and p-value less than 0.05). At the same time, ROA and CGIR also have the negative impact on debt ratio like HHI. Variables GRTA and NDTS do not affect the capital structure of manufacturing enterprises (p-value is greater than 0.05).

Table 4. The result of regression

\begin{tabular}{llll}
\hline \multirow{2}{*}{ VARIABLES } & $\mathbf{( 1 )}$ & $\mathbf{( 2 )}$ & $\mathbf{( 3 )}$ \\
\cline { 2 - 4 } DR $_{\mathrm{t}-1}$ & $\mathbf{F E M}$ & $\mathbf{R E M}$ & $\mathbf{G M M}$ \\
HHI & & & $0.859^{* * *}$ \\
& & & $(0.118)$ \\
ROA & $(0.0839)$ & 0.0333 & $-4.546^{* *}$ \\
& $-0.339^{* * *}$ & $(0.0827)$ & $(2.217)$ \\
SIZE & $(0.0317)$ & $-0.367^{* * *}$ & $-0.257^{* * *}$ \\
& $0.0648^{* * *}$ & $(0.0315)$ & $(0.0778)$ \\
GRTA & $(0.00538)$ & $0.0619^{* * *}$ & $0.0663^{* * *}$ \\
& $0.000632^{* * *}$ & $(0.00459)$ & $(0.0225)$ \\
NDTS & $(0.000118)$ & $0.000604^{* * *}$ & -0.00173 \\
& $0.275^{* * *}$ & $(0.000118)$ & $(0.00258)$ \\
CGIR & $(0.0243)$ & $0.238^{* * *}$ & -0.147 \\
& $-0.0314^{*}$ & $(0.0216)$ & $(0.207)$ \\
Constant & $(0.0181)$ & $-0.0413^{* *}$ & $-0.636^{* * *}$ \\
& -0.749 & $(0.0182)$ & $(0.184)$ \\
Observations & $(1.072)$ & -0.543 & 10.67 \\
R-squared & 1,791 & $(1.076)$ & $(13.96)$ \\
Number of id & 0.246 & 1,791 & 1,791 \\
Hausman test & 262 & & \\
Autocorrelation test & & 262 & 262 \\
Heteroskedasticity test & 0.000 & 0.000 & \\
AR(2) & 0.000 & & \\
Sargan test & & & \\
\hline
\end{tabular}

Note. The dependent variable is DR and the main independent variable is HHI See Table 1 for variable definitions. Standard errors in parentheses; *** $\mathrm{p}<0.01,{ }^{* *} \mathrm{p}<0.05,{ }^{*} \mathrm{p}<0.1$; The GMM model is stablity with AR (2) and Hansen test have p-value greater than 0.05 .

\section{Discussion}

HHI has a negative impact on capital structure of manufacturing enterprises. It can be seen that manufacturing enterprises with high economic potential when highly competitive will create pressure on enterprises with low 
competition by reducing debt in capital structure. It can be seen that manufacturing enterprises do not risk a trade-off between high competition and high debt ratio (not risking in using leverage). With a large amount of long-term asset investment (specific to the manufacturing industry), it will take time to achieve business results or compete in the market. However, businesses avoid risks with cost of debt increases. In addition, businesses with reduced competitiveness tend to borrow more debts (not to use equity) to ensure the value of enterprises in the market. The fact that low-competitive businesses borrow more debt will be subjects them to further pressure due to cost of debt and from businesses with great competitiveness while taking advantage of products to put pressure on lower competitive enterprises

ROA has a negative effect on debt raio manufacturing enterprises. Can see the tax shield is applied by large enterprises in the process of operation. At the same time, businesses do not like to use the advantages of financial leverage in their production and business activities. More efficient businesses have brought in a bigger internal capital (retained earnings). This activity helps businesses be more flexible in selecting investment capital (there are more options when there is an excess of internal capital). The SIZE factor only has a positive impact on the debt raio of enterprises. The expansion of the business scale for enterprises is less of the use of external loans but the use of capital within the enterprise. The pressure of businesses with interest expenses when using too much external loans.

The Capability of generating internal resources has the opposite effect on debt raio, showing that with high financial resources, manufacturing enterprises tend to reduce the debt ratio. This result is consistent with predatory theory: a high-leverage company is threatened by companies with lower financial leverage (Bolton \& Scharfstein, 1990; Brander \& Lewis, 1986; Opler \& Titman, 1994). With the incumbent with deep-pocket, they are willing to come up with price and output policies to create great pressure for new market participants. This action will increase their market share and new entrants may have to withdraw from the market without large financial potential (Gui-Diby, 2016; Guney et al., 2011). Since then, the company will have a policy to encourage debt reduction

NDTS variable does not affect capital structure. This result shows that the use of Non-debt tax shield is not significant in changing the capital structure of manufacturing enterprises. The fact that businesses use depreciation tools or pension funds is not part of the liabilities strategy of businesses. At the same time, the growth of GRTA (total asset growth) does not impact on debt ratio of manufacturing enterprises. This result indicates that the industry requires large assets (production lines, factories) is mandatory. These investments are always in the business plan, so businesses are proactive in some investment items in the future.

\section{References}

Arellano, M., \& Bond, S. (1991), Some Tests of Specification for Panel Data: Monte Carlo Evidence and an Application to Employment Equations, The Review of Economic Studies, 58(2), 277-297. https://doi.org/10.2307/2297968

Barclay, M. J., Smith, C. W., \& Watts, R. L. (1995). The Determinants of Corporate Leverage and Dividend Policies. Journal of Applied Corporate Finance, 7(4), 4-19. https://doi.org/10.1111/j.1745-6622.1995.tb00259.x

Boghean, C., \& State, M. (2015). The Relation between Foreign Direct Investments (FDI) and Labour Productivity in the European Union Countries. Procedia Economics and Finance, 32, 278-285. https://doi.org/10.1016/S2212-5671(15)01392-1

Bolton, P., \& Scharfstein, D. S. (1990). A Theory of Predation Based on Agency Problems in Financial Contracting. The American Economic Review, 80(1), 93-106.

Brander, J. A., \& Lewis, T. R. (1986). Oligopoly and Financial Structure: The Limited Liability Effect. The American Economic Review, 76(5), 956-970.

Fosu, S. (2013). Capital structure, product market competition and firm performance: Evidence from South Africa. The Quarterly Review of Economics and Finance, 53(2), 140-151. https://doi.org/10.1016/j.qref.2013.02.004

GSO. (2019). Manufacturing and processing industry are the main contributor to economic growth. Retrieved from https://bnews.vn/cong-nghiep-che-bien-che-tao-dong-gop-chinh-cho-tang-truong-kinh-te/109635.html

Gui-Diby, S. L. (2016). Impact of foreign direct investments on economic growth in Africa: Evidence from three decades of panel data analyses-ScienceDirect. Retrieved February 24, 2019, from https://www.sciencedirect.com/science/article/pii/S1090944314000192 
Guney, Y., Li, L., \& Fairchild, R. (2011). The relationship between product market competition and capital structure in Chinese listed firms. International Review of Financial Analysis, 20(1), 41-51. https://doi.org/10.1016/j.irfa.2010.10.003

Hausman, J. (1978), Specification tests in econometrics, Econometrica, 46, 1251-1271. https://doi.org/10.2307/1913827

Khan, A. G. (2012), The relationship of capital structure decisions with firm performance: A study of the engineering sector of Pakistan, International Journal of Accounting and Financial Reporting, 2(1), 245-262. https://doi.org/10.5296/ijafr.v2i1.1825

Kovenock, D., \& Phillips, G. (1995), Capital structure and product-market behavior: An examination of plant exit and investment decisions. Review of Financial Studies, 10(3), 767-803. https://doi.org/10.1093/rfs/10.3.767

Lindenberg, E. B., \& Ross, S. A. (1981). Tobin's q Ratio and Industrial Organization. The Journal of Business, 54(1), 1-32. https://doi.org/10.1086/296120

Michaelas, N., Chittenden, F., \& Poutziouris, P. (1999). Financial Policy and Capital Structure Choice in U.K. SMEs: Empirical Evidence from Company Panel Data. Small Business Economics, 12(2), 113-130. https://doi.org/10.1023/A:1008010724051

Mitani, H. (2014), Capital structure and competitive position in product market. International Review of Economics and Finance, 29, 358-371. https://doi.org/10.1016/j.iref.2013.06.009

Moeinaddin, M., Nayebzadeh, S., \& Ghasemi, M. (2013). The Relationship between Product Market Competition and Capital Structure of the Selected Industries of the Tehran Stock Exchange. International Journal of Academic Research in Accounting, Finance and Management Sciences, 3(3), 221-233. https://doi.org/10.6007/IJARAFMS/v3-i3/132

Myers, S. C. (1984). Capital Structure Puzzle (Working Paper No. 1393). National bureau of economic research. https://doi.org/10.3386/w1393

Opler, T. C., \& Titman, S. (1994). Financial Distress and Corporate Performance. The Journal of Finance, 49(3), 1015-1040. https://doi.org/10.1111/j.1540-6261.1994.tb00086.x

Roodman, D. (2006), How to Do xtabond 2: An Introduction to "Difference" and "System" GMM in Stata. Working paper, Center for Global Development, 103. https://doi.org/10.2139/ssrn.982943

\section{Copyrights}

Copyright for this article is retained by the author, with first publication rights granted to the journal.

This is an open-access article distributed under the terms and conditions of the Creative Commons Attribution license (http://creativecommons.org/licenses/by/4.0/). 